\title{
WYKAZ PUBLIKACJI O. PROF. BENIGNUSA WANATA
}

\section{Ksiq̨żki}

1. Zakon Karmelitów Bosych w Polsce, Klasztory karmelitów i karmelitanek bosych 1605-1975, Kraków 1979, Wydawnictwo OO. Karmelitów Bosych, ul. Rakowicka $18,8^{\circ}(24 \times 17 \mathrm{~cm})$, ss. $831,1 \mathrm{nlb}$., il. 212 , w tym 8 kolorowych, mapy, tabele, indeks osób i miejscowości (praca habilitacyjna oparta na szerokiej bazie źródłowej, szczególnie typu archiwalnego, stanowi pierwszą tego rodzaju publikację o zakonie Karmelitów Bosych w Polsce. Nie tylko uzupełnia dotkliwą lukę w historiografii, lecz także koryguje liczne nieścisłości w dotychczasowej literaturze przedmiotu).

2. Kult św. Józefa Oblubieńca NMP u Karmelitów Bosych w Krakowie, Kraków 1981, Wydawnictwo OO. Karmelitów Bosych, ul. Rakowicka $18,12^{\circ}$ (16,5 x 11,7 $\mathrm{cm})$, ss. 230, 2 nlb., il. 28, w tym 11 barwnych, indeks osób i miejscowości (rozprawa doktorska, pisana pod kierunkiem ks. prof. dr. hab. Bolesława Przybyszewskiego na Papieskim Wydziale Teologicznym w Krakowie, prezentuje i omawia w aspekcie historii sztuki i religijności główne sanktuarium św. Józefa na ziemiach Polski w XVII i XVIII w.).

3. Maryjne sanktuarium Karmelitów Bosych w Czernej. Przewodnik, Kraków 1981, Wydawnictwo OO. Karmelitów Bosych, ul. Rakowicka 18, $12^{\circ}(16,4$ x 11,7 cm), ss. 109, 3 nlb., il. 24, w tym 10 barwnych, 2 mapy, 6 grafik (praca, oparta głównie na źródłach archiwalnych, przedstawia w pierwszej części zarys dziejów klasztoru, jego działalność: apostolska, jako sanktuarium Matki Bożej Szkaplerznej, oświatową przez utrzymywanie szkół, artystyczną - przez produkcję wyrobów z czarnego marmuru w Dębniku oraz gospodarczą - przez kulturę agrarna, leśną i kopahnie żelaza oraz ogniotrwałej glinki. W drugiej części zawiera przewodnik ze szczegółowymi opisami architektury, wystroju i wyposażenia wnętrza kościoła jak również klasztoru, zgromadzonych zbiorów dzieł sztuki, biblioteki i archiwum).

4. „Idźcie do Józefa” - Modlitewnik, Kraków 1982, Wydawnictwo OO. Karmelitów Bosych, ul. Rakowicka $18,12^{\circ}(13 \times 10 \mathrm{~cm})$, ss. 220 .

5. Maryjne sanktuarium w Piotrkowicach k. Buska, Kraków 1987, Wydawnictwo OO. Karmelitów Bosych, ul. Rakowicka $18,12^{\circ}$, ss. 172,20 nlb., il. 38 , w tym 8 barwnych.

6. Matka Boska Szkaplerzna w Czernej. Studium ikonograficzno-historyczne, Kraków 1988, Wydawnictwo OO. Karmelitów Bosych, ul. Rakowicka 18, 12º ss. 194, 2 nlb., il. 20. 
7. Na szlaku „, Orlich Gniazd”, Sanktuarium Matki Boskiej Szkaplerznej w Czernej, Kraków 1991, Wydawnictwo OO. Karmelitów Bosych, ul. Rakowicka 18, 12², ss. 180, il. barwnych 217.

8. Maryjne sanktuarium karmelitów bosych w Czernej. Przewodnik, wyd. II uzupełnione, Kraków 1992, Wydawnictwo OO. Karmelitów Bosych, ul. Rakowicka $18,12^{\circ}$, ss. 151,1 nlb., il. 40 , w tym barwnych 32,6 grafik, 2 mapy.

9. Szkaplerz znakiem oddania się Maryi. Sanktuarium Matki Bożej Szkaplerznej, Czerna 1994, ss. 64, il. 9.

10. Katalog Archiwum Krakowskiej Prowincji Karmelitów Bosych pw. Ducha Świętego, tom I: Dokumenty i Zespoty Archiwalne, Kraków 1998, ss. 496.

11. Sanktuarium Matki Bożej Szkaplerznej w Berdyczowie, Kraków 1998, ss. 64, 32 nlb., i1. 44.

12. Sanktuarij Materi Bożoj Szkaplernoj w Berdicewi, Kraków 1998, ss. 55, 37 nlb., il. 44.

13. Katalog Archiwum Krakowskiej Prowincji Karmelitów Bosych pw. Ducha Świętego, tom II: Zbiory i spuścizny zakonników oraz kartografia, Kuria Krakowskiej Prowincji Karmelitów Bosych, Kraków 1999, ss. 187.

14. Udział Najświętszej Maryi Panny w zbawczym dziele Trójcy Świętej w karmelitańskiej ikonografii, [w:] Życie i misja Karmelu Terezjańskiego, nr 72, Kuria Krakowskiej Prowincji Karmelitów Bosych, Kraków 2000, ss. 68, il. 30.

15. Z dziejów kultu Matki Bożej w Zakonie Karmelitów, [w:] Życie i misja Karmelu Terezjańskiego, nr 76, Kuria Krakowskiej Prowincji Karmelitów Bosych, Kraków 2000 , ss. 52 , il. 18.

16. Zycie i działalnośc karmelitów bosych w diecezji kamienieckiej w latach 1622 1866, Kuria Krakowskiej Prowincji Karmelitów Bosych, Kraków 2001, s. 76, il. 9, 1 mapa, 3 tabele.

17. Święty Józef Protektorem Zakonu Karmelitańskiego, Kuria Krakowskiej Prowincji Karmelitów Bosych, Kraków 2001, s. 88, il. kol. 7, il. biało-czarnych 19.

18. Drukarnia Karmelu Fortecy Najświętszej Maryi Panny w Berdyczowie. Działalność wydawnicza i poligraficzna karmelitów bosych w Berdyczowie na Ukrainie, Wydawnictwo Karmelitów Bosych, Kraków 2002, ss. 167, 33 nlb, il. 33.

19. Zarys rozwoju kultu Matki Bożej Milosierdzia z Ostrej Bramy, Kuria Krakowskiej Prowincji Karmelitów Bosych, Kraków 2003, ss. 62, 2 nlb., il. 37, w tym 26 barwnych.

20. Przyjaźń o. Wacława Nowakowskiego OFM Cap. z o. Rafatem Kalinowskim OCD, Kuria Krakowskiej Prowincji Karmelitów Bosych, Kraków 2003, ss. 60, $4 \mathrm{nlb}$., il. 12.

21. Kult Matki Bożej w klasztorze OO. Karmelitów Na Piasku w Krakowie jako element charyzmatu karmelitańskiego, De Arte Lańcut 2004, ss. 96, il. wbw. XVI, 18.

\section{Broszury}

1. Rola sanktuariów maryjnych archidiecezji krakowskiej w ksztaltowaniu życia religijnego, Kraków 1988, Wydawnictwo Kurii Metropolitalnej, ss. 22.

2. Matka Boska Szkaplerzna w Czernej, Kraków 1988, Wyd. Duszpasterstwo Kurii Metropolitalnej, ss. 22.

3. Krzyżowiec Maryi. Zycie i dzieło o. Gabriela Jacquiera CM (1906-1942), Kraków 1996, ss. 32, il. 2.

4. Sztuka w Karmelu, Kraków 1999, ss. 41. 


\section{Artykuty w opracowaniach zbiorowych}

1. Bibliografia św. Teresy od Jezusa w Polsce, [w:] Otrzymatam ducha madrości, Ksiega pamiątkowa z okazji ogłoszenia św. Teresy od Jezusa Doktorem Kościoła Powszechnego, Kraków 1972, Wydawnictwo OO. Karmelitów Bosych, $8^{\circ}(23 \times 16,5 \mathrm{~cm})$, s. 379-396 (przyczynkiem do ogólnych dziejów kultury jest ustalenie 124 pozycji bibliograficznych zwartych druków, w tym 27 starodruków nie notowanych w Bibliografii polskiej Estreichera).

2. Kult Matki Bożej w Zakonie Karmelitów Bosych w XIX wieku, [w:] Niepokalana kult Matki Bożej na ziemiach polskich w XIX wieku, pod red. ks. bp. B. Pylaka i ks. Cz. Krakowiaka. Księga pamiątkowa V Ogólnopolskiego Kongresu Mariologicznego i Maryjnego, Lublin 1988, s. 403-417.

3. Walory artystyczne i zatozenia ideowe obrazu św. Józefa z kościota SS. Karmelitanek Dawnej Obserwancji w Dubnie oraz rozwój jego kultu w XVIII $i$ XIX wieku, „Studia Józefologiczne - Materiały z sympozjów Józefologów Polskich w Kaliszu", II (1990).

4. Sanktuarium św. Rafata Kalinowskiego w Czernej, [w:] Swiety Rafat Kalinowski -Ksiega pamiatkowa, Kraków 1993, s. 138-142.

5. Zakonotwórcza myśl o. Anzelma od św. Andrzeja Corsini OCD, [w:] Dni Karmelitańskie $w$ Łodzi, poświęcone życiu $i$ duchowości o. Anzelma od św. Andrzeja Corsini OCD (Macieja Gadka), z okazji setnej rocznicy jego urodzin i piętnastej śmierci 24 II 1884 - 15 X 1969, Warszawa-Marki 1994, s. 89-103.

6. Wktad i zasługi włoskich karmelitów bosych w powstanie prowincji Ducha Świętego w Polsce w I pol. XVII wieku, ,Analecta Cracoviensia” XXVII (1995), s. 637-651.

7. Il contributo dei Carmelitani scalzi d'Italia alla fondazione della provincia dello Spirito Santo in Polonia nella prima meta del secolo XVII, [w:] Nicoló Doria Itinerari economici, culturali, religiosi nei secoli XVI-XVII tra Spagna, Genova e I'Europa. Atti del Convegno Internazionale di Studi Genova, 8-10 ottobre 1994 a cura di Silvano Giordano - Claudio Paolocci, Genova 1996, s. 687-697.

8. Walory artystyczne i zatozenia ideowe obrazu św. Józefa z kościola SS. Karmelitanek w Dubnie. Rozwój jego kultu w XVIII $i$ XIX w., ,Folia Historica Cracoviensia" vol. 3 (1996), s. 113-134.

9. Kult Matki Bożej w klasztorze OO. Karmelitów na Piasku w Krakowie i jego promocja w Polsce, „Folia Historica Cracoviensia”, vol. 4-5, (1997-1998), s. 185-213.

10. B. J. Wanat OCD, Sz. T. Praśkiewicz OCD, Śp. o. Michat Machejek OCD (1918-1998), Rzym 1998.

11. Historia nabożeństwa szkaplerznego w Karmelu, [w:] Apostolat zwiazany ze szkaplerzem karmelitańskim. Historia, teologia, praktyki duszpasterskie. Materiaty z II. Forum Duszpasterskiego Kraków 6-7 października 1998 r., Kraków 1998, s. 6-21.

12. Śp. O. Michat od Jezusa, Maryi, Józefa (Tadeusz Machejek 1918-1998) OCD, [w:] Biegli w postępowaniu kanonizacyjnym, Materiaty IV Ogólnopolskiego Sympozjum Prawa Kanonizacyjnego, KUL Lublin 22-23 V 1998, pod red. ks. H. Misztala i W. Bara OFM Conv, Lublin-Tarnów 1999, s. 154-161.

13. Marcin (Campius) Wadowita (1567-1641), [w:] Złota księga Papieskiej Akademii Teologicznej, pod red. S. Piecha, Kraków 2000, s. 249-260.

14. Karmelitańska sztuka, [w:] Encyklopedia katolicka, tom VIII, Towarzystwo Naukowe Katolickiego Uniwersytetu Lubelskiego, Lublin 2000, kol. 838-848.

15. Udzial Najświętszej Maryi Panny w zbawczym dziele Trójcy Świętej w karmelitańskiej ikonografii, [w:] Trójca Święta a Maryja. Materiaty z sympozjum mario- 
logicznego, zorganizowanego przez Polskie Towarzystwo Mariologiczne, Częstochowa, 6-8 września 1999 roku, pod red. ks. T. Siudy i K. Peka MIC, Częstochowa 2000, s. 203-226.

16. Zycie zakonne ojca Daniela Rufeisena, [w:] O. Daniel Maria od Najśw. Serca Pana Jezusa, karmelita bosy, (Oswald Rufeisen), Połknałem haczyk Królowej Karmelu, Autobiografia, opracowanie i posłowie Benignus Józef Wanat OCD, Wydawnictwo Karmelitów Bosych, Kraków 2001, s. 215-251.

17. Opracowanie i posłowie, [w:] Maria Ksawera Czartoryska OCD. Reforma Czernej - Największe Miłosierdzie Boże, „Nasza Przeszłość”, t. 95:2001, s. 261-356.

18. Zycie $i$ działalność karmelitów bosych $w$ diecezji kamieniecko-podolskiej $w$ latach 1622-1866, [w:] Pasterz i twierdza, Ksiega jubileuszowa dedykowana księdzu biskupowi Janowi Olszańskiemu, ordynariuszowi diecezji w Kamieńcu Podolskim, pod red. ks. J. Wołczańskiego, Kraków-Kamienic Podolski 2001, s. 323-356.

19. Matka Boża Szkaplerzna prowadzqca do Ojca przez Chrystusa w Duchu Świętym, [w:] Szkaplerz Karmelitański, Biblioteka Zeszytów Karmelitańskich, nr 3, Wydawnictwo Flos Carmeli, Poznań 2002, s. 50-58.

20. Wstepp, [w:] Ks. Bolesław Przybyszewski, Adam Stefan Kardynał Sapieha, pasterz dobry, ksiaze nieztomny 1867-1851, redakcja i opracowanie I. Platowska-Sapetowa, Wydawnictwo De arte, Lańcut 2002, s. 9-14.

21. Kluz Mieczysław OCD, [w:] Encyklopedia katolicka, t. IX, Lublin 2002, s. 174.

22. Kult Matki Mitosierdzia w Karmelu $i$ w Kościele Polskim, [w:] Szkaplerz Maryi znakiem Bozego Mitosierdzia. Wybrane materiaty z obchodów IV Ogólnopolskiego Spotkania czcicieli Matki Bożej Szkaplerznej, Czerna, 20 lipca 2002 r., Kuria Krakowskiej Prowincji Karmelitów Bosych, Kraków 2002, s. 29-39.

23. Z dziejów kultu Matki Bożej Miłosierdzia z Ostrej Bramy, [w:] Studia i rozprawy ofiarowane profesorowi Tytusowi Górskiemu. Charisteria Titto Górski oblata, Kraków 2003, Wydawnictwo Naukowe PAT, s. 287-308.

24. Godyń Hipolit (1919-1997), karmelita bosy, imię zakonne Apoloniusz od Niepokalanego Poczęcia NMP, [w:] Leksykon duchowieństwa represjonowanego w PRL w latach 1945-1989, t. II, praca zbiorowa pod red. J. Myszora, przy współudziale J. Zurka, Verbinum - Wydawnictwo Księży Werbistów, Warszawa 2003, s. 75.

25. Gut Wladystaw (1911-1976), karmelita bosy, imię zakonne Pawel od św. Piotra, [w:] Leksykon duchowieństwa represjonowanego, op. cit., s. 83-84.

26. Jabłoński Stanisław (1910-1978), karmelita bosy, imię zakonne Bazyli od św. Anzelma, [w:] Leksykon duchowieństwa represjonowanego, op. cit., s. 93-94.

27. Kupny Pawet Karol (1921-1999), karmelita bosy, imię zakonne Herman od Najświętszego Sakramentu, [w:] Leksykon duchowieństwa represjonowanego, op. cit., s. 147-149.

28. Piekarczyk Józef (1902-1976), karmelita bosy, imię zakonne Konrad od Aniołów, [w:] Leksykon duchowieństwa represjonowanego, op. cit., s. 216-217.

29. Rytko Jan (1922-1978?), karmelita bosy, imię zakonne Henryk od Zwiastowania NMP, [w:] Leksykon duchowieństwa represjonowanego, op. cit., s. 250-251.

30. Trzeciak Wtadysław (1906-1982), karmelita bosy, imię zakonne Elizeusz [od Matki Bożej Szkaplerznej], [w:] Leksykon duchowieństwa represjonowanego, op. cit., s. 300-302.

31. Wstęp, [w:] Tajemnica życia w Maryi wedtug zapisków o. Gabriela Jacquiera CM, wydanie II, uzupełnione i poprawione, wybór i opracowanie E. Stolarczyk, Kraków 2003, s. 9-14. 


\section{Artykuty w czasopismach}

1. Echo przesztości, ,Juventus Teresiana” nr 5(7):1957, s. 33-35.

2. Opiekuńcze duchy Wiśniowca, „Juventus Teresiana” nr 3(11):1958, s. 153-160; nr 4(12):1958, s. 137-144.

3. Szerokie serce (o św. Teresie od Jezusa z okazji 400-lecia reformy zakonu karmelitańskiego 1562-1962), „Gość Niedzielny” nr 34:1961, s. 268-269.

4. Przyczyny upadku prowincji Ducha Swiętego i reforma klasztoru Karmelitów Bosych w Czernej w 1880 r., ,Karmel” nr 4:1981, s. 7-26.

5. Karmelitański jubileusz (omówienie jubileuszu 400 lat śmierci św. Teresy od Jezusa, Doktora Kościoła), „Niedziela” nr 32:24 X 1982, s. 1.

6. Kaplica i muzeum bt. Rafata Kalinowskiego w Czernej, „Karmel” 1983, s. 43-55.

7. Le tableau et le culte de s. Joseph au couvent des carmes dechaux de Cracovie a Podzamcze au XVII siecle, „Presencia de San Jose en el siglo XVII”, Actas del Cuarto Simposion Internacional, Valladolid 1987, s. 493-503; „Ateneum Kaplańskie" 465-466 (1986), s. 262-273.

8. Kult Matki Bozej w Zakonie Karmelitów Bosych na ziemiach polskich w XIX wieku, „Karmel” grudzień 1986, s. 26-39.

9. Matka Boska Szkaplerzna w Czernej, „Notificationes e Curia Metropolitana Cracoviensi" nr 1-2:1988, s. 21-36.

10. Koronacja Matki Boskiej Szkaplerznej w Czernej, „Karmel” czerwiec 1988, s. 3-11.

11. Obecność Karmelitów Bosych na ziemiach wschodnich Polski przedrozbiorowej, „Karmel” nr 2:1991, s. 57-62; nr 3:1991, s. 60-62.

12. Promieniowanie nowej gwiazdy Karmelu, List okólny prowincjała do klasztorów prowincji Ducha Świętego po kanonizacji Ojca Rafała Kalinowskiego, ,Biuletyn Rodziny Karmelitańskiej" nr 3: 1991, s. 9-17.

13. Objęcie i poświęcenie kościola - sanktuarium Matki Bożej Szkaplerznej przez karmelitów bosych w Berdyczowie na Ukrainie, „Biuletyn Rodziny Karmelitańskiej" nr 3(1991), s. 24-25.

14. La sua vita testimonia un grande valore del consacrato a Cristo, „L'Osservatore Romano" (16 novembre 1991), s. 7.

15. Modlitewne dialogi Anny Marii, „Karmel" nr 1:1992, s. 41-46.

16. Zakonspirowany w klasztorze żolnierz Armii Krajowej z Wilna, „Kurier Wileński” nr 248 (18 grudnia 1992), s. 6.

17. Ogólnopolskie dziękczynienie za dar św. Rafała Kalinowskiego, „Biuletyn Rodziny Karmelitańskiej" nr 5:1992, s. 2-3.

18. Krótka geneza przyszłego podziału prowincji, „Biuletyn Rodziny Karmelitańskiej” nr 6: 1992, s. 12.

19. Ważniejsze wydarzenia z życia prowincji w mijajacym triennium (wyjęte ze sprawozdania o stanie prowincji na Radzie Plenarnej 19 lutego 1993 r.), „Biuletyn Rodziny Karmelitańskiej" nr 7:1993, s. 11-16.

20. Tajemnica zycia w Maryi, „Karmel” nr 2(47):1993, s. 46-51.

21. Biografie: br. Bonawentura Gonciarz, o. Onufry Walczak, o. Andrzej Bobola Zajdler, „Życie Karmelu” nr 3(1993), s. 33-42.

22. Opiekuńcze duchy Wiśniowca, "Wołyń i Polesie”, nr 4:1994, s. 6-9; nr 1(5):1995, s. 10-15; nr 2(6):1995, s. 5-10; nr 3(7):1995, s. 6-10; nr 4(8):1995, s. 9-10.

23. Koronacja nowego obrazu Matki Boskiej Szkaplerznej w Berdyczowie na Ukrainie, „Karmel” nr 3(1998), s. 64-72.

24. O. Emil od Wniebowzięcia NMP (Walenty Hebda 1915-1997) OCD, „Życie Karmelu", nr 29(1998), 49-54. 
25. O. Michat od Jezusa, Maryi, Józefa (Tadeusz Machejek) OCD, „Życie Karmelu” nr 33(1998), s. 87-98.

26. O. Daniel-Maria od Najśw. Serca Pana Jezusa (Oswald Józef Rufeisen) OCD, „Życie Karmelu” nr 33(1998), s. 87-98.

27. O. Gracjan Maria od św. Teresy (Stanistaw Batys 1930-1999) OCD, „Życie Karmelu" nr 35(1999), s. 85-90.

28. O. Rudolf od Przebicia Serca św. M. Teresy (Stanistaw Warzecha 1919-1999) $O C D$, „Życie Karmelu” nr 36(1999), s. 82-93.

29. O. Wtadystaw Majta (1923-2000) OCD, ,Życie Karmelu”, nr 43(2000), s. 77-81.

30. Marcin Kępa (Campius) Wadowita (1567-1641), „Wadoviana - Przegląd Historyczno-Kulturalny" nr 5(2000), s. 92-99.

31. Laskami stynaca rzeźba Matki Boskiej Płaczacej w Dębowcu, „Folia Historica Cracoviensia" vol. VII, 2000, s. 139-147.

32. Koronacja nowego obrazu Matki Boskiej Szkaplerznej w Berdyczowie na Ukrainie, „Folia Historica Cracoviensia” vol. VII, 2000, s. 191-204.

33. Ikonografia Trójcy Świętej, „Zeszyty Karmelitańskie - Pismo poświęcone duchowości" nr 3(13):2000, s. 61-68.

34. Zycie zakonne ojca Daniela Rufeisena, [w:] O. Daniel Maria od Najśw. Serca Pana Jezusa, karmelita bosy (Oswald Rufeisen), Połknałem haczyk Królowej Karmelu. Autobiografia, Wydawnictwo Karmelitów Bosych, Kraków 2001, s. 215-251 .

35. Z dziejów kultu Matki Bożej w tradycji karmelitańskiej, „Zeszyty Karmelitańskie” nr 2(15):2001, s. 30-46.

36. Św. Józef Protektorem Zakonu Karmelitańskiego, „Karmel” nr 1:2001, s. 63-73.

37. Z dziejów kultu Matki Bożej w Zakonie Karmelitów, „Karmel” nr 3:2001, s. 14-31.

38. Drukarnia i Wydawnictwo Karmelitów Bosych w Berdyczowie, „Karmel” nr 4:2001, s. 34-49.

39. O. Jan Chrzciciel od Jezusa i Maryi (Stanistaw Piotr Kotaczek 1921-2003), Munster, ,Życie Karmelu” nr 63(2003), s. 95-105.

40. O. Cherubin od Najśw. Maryi Panny (Stanistaw Pikoń, 1921-2003), Czerna, „Życie Karmelu" nr 66(2004), s. 107-119.

41. Drukarnia i wydawnictwo karmelitów bosych w Berdyczowie, „Analecta Cracoviensia", t. XXXV, Kraków 2004, s. 439-470.

\section{Komunikaty}

1. Kult Matki Milosierdzia w Karmelu i w Kościele polskim, [w:] Szkaplerz Maryi znakiem Bożego Milosierdzia. Wybrane materialy z obchodów IV Ogólnopolskiego Spotkania czcicieli Matki Bożej Szkaplerznej, Czerna 20 lipca 2002 r, Kraków 2002, s. 2939. 
Recenzje prac naukowych

Rok 1991

Recenzje prac magisterskich

Małgorzata Borowska Kinder, Rzeźby Lehnerta na Skałce, ss. 104, i1. 23, Warszawa-Kraków 18.06.1991.

Honorata Kotapska, Dwie monstrancje ślaskie w zbiorach krakowskich, ss. 120, il. 6, Warszawa-Kraków 3.12.1991.

Rok 1992

Recenzje prac magisterskich

Tobiasz Zarzecki OCD, Architektura kościola i klasztoru Karmelitów Bosych pod wezwaniem św. Józefa w Wadowicach, ss. 88, il. 20, Kraków-Warszawa, 16.03.1992.

Rok 1993

Recenzje prac magisterskich

Waldemar Polachowski, Życie i twórczość Łukasza Orlowskiego malarza krakowskiego XVIII wieku, ss. 114, il. 23, Warszawa-Kraków 4.04.1993.

Elżbieta Zdanowicz, Cudowny krucyfiks i jego kaplica w Mogile, ss. 84, il. 18, Kraków 19.05.1993.

Grzegorz Niesporek, Malowidla $w$ kapitularzu cysterskim $w$ Mogile, ss. 112, i1. 22, Kraków, 2.06.1993.

Mirosława Apostoł OP, Obraz Marii Magdaleny z klasztoru Sióstr Prezentek i problem aktualności przedstawień świętej w Krakowie $w$ XVI-XVIII wieku, ss. 98, il. 31, Kraków 10.09.1993.

Rok 1994

Recenzje prac magisterskich

S. Immaculata Alina Kraska CSS, Wartości ideowe Zakonu Ducha Ś wietego w malarstwie kosciola Sw. Krzyża w Krakowie, ss. 154, nlb 1, il. 18, Kraków 3.03.1994.

Elżbieta Piwowarczyk, Sztuka sakralna w Dobczycach (historia i dzień dzisiejszy, ss. $134+70$ aneksów, 112 foto, Kraków 17.04.1994.

Marek Rybowicz, Architektura $i$ wystrój kościoła Św. Tomasza Apostoła w Krakowie, ss. 116, nlb 1, il. 54 + 5 rys. pomiarowych, Kraków 25.10.1994.

Zbigniew Romanowski, Katedra św. Jura we Lwowie w latach 1744-1772. Architektura, rzeźba oraz malarstwo sakralne, ss.110, nlb 3, il. nlb 41, Kraków 28.11.1994.

Andrzej Florczak, Kaplica Zbójecka w Zawoi Policznem pod wezwaniem Sw. Jana Chrzciciela, ss. 96, i1. 28, Kraków 29.11.1994.

Rok 1995

Recenzje prac magisterskich

s. Ewa Gleń, Dzieje klasztoru SS. Karmelitanek Dzieciatka Jezus w Czernej (1938-1988), ss. 138, il. 8, Kraków 25.05.1995. 
Janusz Cyprian Moryca OFM, Obraz Matki Bożej kalwaryjskiej. Wybrane zagadnienia z ikonografii Eleusy w Polsce, ss. XXVIII, 124, i1. 65, Kraków 25.05.1995.

Robert Ślusarek, Restauracja kościoła i klasztoru OO. Augustianów na Kazimierzu w Krakowie w XIX wieku oraz w I polowie XX wieku, ss. 75, il. $27+7$ rys., Kraków 15.06.1995.

Rok 1996

Recenzje prac magisterskich

Renata Majchrowicz, Zabytki gotyckiego zlotnictwa ze skarbca kościota parafialnego św. Klemensa w Wieliczce, ss. 57, il. 9, Kraków 13.02.1996.

Dariusz Rozum MS, Kaplica na Murawiance. Easkami stynaca figura Matki Boskiej Anielskiej, ss. 83, nlb. 9, il. 9, Kraków 06.04.1996.

S. Konrada Mariola Dębicka, Sł. NSJ, Kościót i zespól klasztorny Zgromadzenia Słuzebnic Najświętszego Serca Jezusowego w Krakowie, ss. 132, il. 37, Kraków 01.06.1996.

Miłosz Zelk, Dzieje parafii pod wezwaniem SS. Matgorzaty i Katarzyny w Kętach w okresie II Rzeczypospolitej, ss. 122, il. 11 + tabele ze statystykami, Kraków 01.06.1996.

Rok 1997

Recenzje prac magisterskich

Dk Zbigniew Pytel, Architektura obiektów sakralnych projektowanych przez Stanisiawa Witkiewicza w stylu zakopiańskim na przetomie XIX i XX wieku, ss. 297, ilustr. 180, Kraków 13.01.1997.

Bronisław Świętosław Syworyński OFM, Treści ideowe oltarza św. Franciszka z Asy$\dot{z} u$ w Bazylice OO. Bernardynów w Leżajsku, ss. XVI, 101, il. 36, Kraków 07.02.1997.

Piotr Szweda, Mitra biskupia, jej historia, forma $i$ symbol, ss. 98, il. 7, Kraków 08.02.1997.

Dariusz Nowakowski, Chrzcielnica. Studium historyczno-liturgiczne na przykladzie wybranych pamiqtkowych chrzcielnic pochodzacych z tereniu Archidiecezji Krakowskiej, ss. 132 w tym il. XXIX, Kraków 10.02.1997.

Elżbieta Gaura, Kaplica św. Anny w Nowym Targu jako przyklad drewnianego kościoła na Podhalu, ss. 102, il. 33, Kraków 11.02.1997.

Joanna Wiśniewska, Architektura $i$ wystrój kościoła OO. Karmelitów Bosych w Krakowie przy ul. Rakowickiej 18, ss. 106, nlb 25, il. XVI, 28, Kraków 11.02.1997.

Krzysztof Kwaśniewicz, Witraże o tematyce sakralnej w twórczości Adama Bunscha, ss. 106, il. 33, Kraków 04.06.1997.

Anna Glaza, Komplet szat liturgicznych z klasztoru sióstr klarysek w Krakowie z lat 1880-1883. Refleks kultu bt. Salomei, ss. 99, il. 38, 30.09.1997.

Stanisław Cichoń, Kościól Dominikanów w Żólkwi: zabytek sztuki i kultury religijnej, ss. 162, ilustr. 44, Kraków 01.10.1997. 
Rok 1998

Recenzje prac magisterskich

Miłosław Wojciech Goraj OFM, Treść wystroju figuralnego prospektu i chóru organowanego nawy pótnocnej w Bazylice Ojców Bernardynów w Lezajsku, ss. 182,w tym il. 69, Kraków 14.02.1998.

Eugeniusz Marek Kaczor OFM, Katafalk Potockich z 1772 roku na tle staropolskiej obyczjowości pogrzebowej, ss. 154, w tym il. 62, Kraków 14.02.1998.

Małgorzata Habuda, Architektura $i$ wystrój kościola pw. Sw. Proroka Eliasza w Czernej, ss. 123, nlb 13, il. 42, Kraków 19.05.1998.

Aleksandra Ochel, Program ideowy malarstwa w kościele św. Eliasza w Czernej, ss. 52, 34 nlb ilustracji i aneksów, Kraków 23.05.1998.

Elżbieta Noga, Ottarz główny w pokarmelitańskim kościele Niepokalanego Poczęcia NMP /zwanym św. Eazarza/ jako przyktad Theatrum Sacrum, ss. 81, il. 32, Kraków 11.11.1998.

Lucyna Rotter, Historyczne $i$ artystyczne aspekty kościola pw. Sw. Mikołaja w Czulicach, ss. 83, nlb 44, ilustr. 64, Kraków 03.06.1998.

Recenzje prac licencjackich

Mgr Robert Ślusarek, Restauracja kościola i klasztoru OO. Augustianów na Kazimierzu w Krakowie w XIX wieku oraz w I polowie XX wieku, ss. 75, il. $27+7$ rys., Kraków 14.02.1998.

Rok 1999

Recenzje prac magisterskich

Władysław Jasica, Rozwój barokowej snycerki od końca XVII wieku do 1760 roku na przykladzie wnętrza kościoła Karmelitów na Piasku w Krakowie, ss. 80, nlb 3, il. 13, Kraków 07.03.1998.

Angelika Łagoda, Kościót w Radaczu jako przyktad budownictwa szkieletowego Pomorza Zachodniego, ss. 89, il. barw. 28, Kraków 20.06. 1999.

Przemysław Lason, Portrety Agnieszki z Tẹcyńskich Firlejowej z klasztoru OO. Karmelitów Bosych $w$ Czernej i problem ich aktualności na tle XVII-wiecznego portretu w Polsce, ss. 81, w tym il. wbw. 29, Kraków 20.06.1999.

Magdalena Jędrzejczyk, Architektura $i$ wyposazenie kościoła pod wezwaniem św. Jana Chrzciciela $i$ św. Jana Ewangelisty w Krakowie w kontekście jego dziejów, ss. 108, il. 21, Kraków 06.12.1999.

Rok 2000

Recenzje prac magisterskich

Lucjan Bartkowiak CR, Treści ideowe piętnastowiecznego malowidla ściennego w krużgankach franciszkańskich $w$ Krakowie z Chrystusem w ttoczni mistycznej, ss. $78+8$ i1., Kraków 15.02.2000.

Marta Kuchcicka, Architektura $i$ wyposażenie kościola pw. Sw. Bartłomieja w Mogile, ss. 100, il. 30, Kraków 28.03.2000. 
Anna Szybalska, Program ideowy $i$ artystyczny ikonostasu z cerkwi pod wezwaniem śś. Kosmy i Damiana w Kotaniu, ss. 8628 wbw. il. i mapy, Kraków 29.05.2000.

Jolanta Woźniak, Architektura i wystrój kościola pod wezwaniem ŚŚ. Apostolów Piotra i Pawła w Stopnicy, ss. 109, w tym 30 il. wbw., Kraków 29.05.2000.

Agata Ptaszkowska, Malarstwo Ignacego Monti w akademickiej kolegiacie pw. św. Anny w Krakowie, ss. 79, il.19, Kraków 03.06.2000.

Mikołaj Schabowski, Historia i zabytki kościola pod wezwaniem Św. Idziego w Krakowie, ss. 78, il. 60, Kraków 03.06.2000 (praca magisterska z kwalifikacją na pracę licencjacka).

Grzegorz Sabat, Kościól Najświętszego Salwatora na Zwierzyncu w świetle ostatnich badań, ss. 69, il. 77, Kraków 04.06.2000.

Łucja Marek, Matka Boska Spytkowicka (dzieto Józefa Kopaczyńskiego) - krakowskie malarstwo religijne $w$ stużbie Kościołowi, ss. 107, il. 178, aneksów XIV, Kraków 13.06.2000.

Tadeusz Żaba, Ottarz św. Marii Magdaleny w kościele OO. Karmelitów na Piasku w Krakowie, ss. 100, il. 16, Kraków 18.06.2000.

Barbara Grelowska, Szkolnictwo zeńskie w Krakowie w latach 1623-1795 na przykladach szkól Prezentek $i$ Wizytek, ss. 71, Kraków 07.12.2000.

Dominik Słowik, Architektura $i$ wystrój kościoła pod wezwaniem Św. Trójcy na Kazimierzu w Krakowie, ss. 125, w tym 53 il. wbw., Kraków 11.12.2000.

Recenzje prac licencjackich

Ks. Pavol Parnican, Kostol Sv. Katariny v Kremnicy, ss. 71, il. 19, Kraków 22.05.2000.

Recenzje rozpraw habilitacyjnych

Ocena dorobku naukowego i rozprawy habilitacyjnej ks. dra Zdzisława Klisia nt. $P a$ ruzja. Przedstawienie Sadu Ostatecznego w sztuce średniowiecznej Europy Srodkowej, Kraków 31.03.2000 r.

Rok 2001

Recenzje prac magisterskich

Anna Kubacka, Liturgia i sztuka w świetle publikacji Misterium Christi, Analecta Cracoviensia oraz Ruchu Biblijnego i Liturgicznego, ss. 118, Kraków 27.02.2001.

Joanna Słoboda, Czarny marmur w kościele Mariackim jako przejaw tenebryzmu. Ze studiów nad barokizacja fary krakowskiej, ss.152, i. 20, Kraków 18.06.2001.

Wojciech Bargiel, Historia Krakowskiego Zakładu Witrazów i Mozaiki S. G. Zeleński do roku 1952 oraz wybrane realizacje, ss. 112, il. wbw. 9, Kraków 19.06.2001.

Tomasz Glą, Blogoslawiony ks. Emil Szramek - mecenas sztuki i kolekcjoner, ss. 86, il. wbw. 25, Kraków 19.06.2001. 
Maciej Olborski, Odbicie kultu św. Stanislawa na przelomie XV i XVI wieku w sztuce Krakowa, ss. $103+17$ il. wbw., Kraków 19.06.2001 (praca magisterska z kwalifikacją na pracę licencjacka).

Elżbieta Macioł, Problematyka rzeźby krakowskiej końca XVII wieku w zespole pustelni b1. Salomei w Grodzisku, ss. 83, cz. II il. 74. Kraków 22.06.2001.

Witold Markiewicz, Historia, architektura i wyposażenie kościola ŚŚ. Marcina i Józefa Sióstr Karmelitanek Bosych w Krakowie w XVII-XVIII wieku, ss. 71, il. 26, 3 aneksy, Kraków 16.12.2001.

Malgorzata Milc, Wartości artystyczne kościoła w Zatorze, ss. 163, il. 96, Kraków 17.12.2001.

Recenzje prac licencjackich

Ks. Donat Carnogurski, Umenie v chrame Sv. Jakuba v Levoci, ss 193, il. 74, Kraków 18.06.2001.

Recenzje rozpraw doktorskich

Aneta Kramiszewska, Visio religiosa w polskiej sztuce barokowej, obronionej na Wydziale Nauk Humanistycznych KUL, Kraków 10.01.2001 r.

Rok 2002

Recenzje prac licencjatu zawodowego

Grzegorz Majewski, Historia i sztuka kaplic bliźnich w bazylice OO. Cystersów w Mogile, ss.61, il. 35, Kraków 23.09.2002.

Marcin Michalski, Architektura sakralna Księzy Misjonarzy na podstawie kościoła bt. Anieli Salawy w Krakowie, ss. 50, il. 2, Kraków 24.09.2002.

Kama Bella, Malarstwo Jana Bakowskiego w klasztorze karmelitów bosych przy ul. Rakowickiej w Krakowie, ss. 44, il. 10, Kraków 25.09.2002.

Maricin Chlanda, Wptyw kultu s'w. Jana Kantego na wystrój kolegiaty św. Floriana w Krakowie, ss. 52, il. 28, Kraków 25.09.2002.

Magdalena Czechowska, Malarstwo religijne Pawła Gołębiowskiego w klasztorze karmelitów bosych w Czernej z XVIII wieku, ss. 28, il. 7, Kraków 25.09.2002.

Marcin Grochala, Cykl 14 obrazów w stalach kościola Bożego Ciała w Krakowie $w$ świetle walki z reformacja, ss. 38, il. 14, Kraków 25.09.2002.

Agnieszka Wolczyńska, Gotycka rzeźba w bazylice mniejszej pw. sw. Andrzeja Apostola w Olkuszu, ss. 52, il. 10, Kraków 19.11.2002.

\section{Recenzje prac magisterskich}

Szymon Kurpios, Malarstwo religijne Wastimila Hofmana, Kraków 29.01.2002.

Paweł Ferko OCD, Walory artystyczne i program ideowy kaplicy pod wezwaniem Matki Bożej Częstochowskiej w Kluszkowcach oraz jej zabytki sztuki, ss. 93, rys. 2, il. 13, Kraków 16.02.2002 (praca magisterska z kwalifikacją na pracę licencjacka). 
Ks. Jan Kudelka, Portrety biskupów tarnowskich, ss. 113, w tym il. $50+12$, Kraków 11.03.2002.

Mariola Książek, Parafia Niepokalanego Serca Najświętszej Maryi Panny w Grodzisku w latach 1935-2000, ss. 114, nlb. 4, il. 5, mapa 1, Kraków 04.04.2002.

Maja Szelerewicz, Kościól pw. św. Wojciecha i Matki Boskiej w Modlinicy pod Krakowem, ss. 187, il. wbw. 95, Kraków 05.04.2002.

Jowita Migdał, Historia, architektura, wyposażenie kościoła pod wezw. Narodzenia św. Jana Chrzciciela w Chetmie, ss. 109, il. wbw. 46, Kraków 27.05.2002 (praca magisterska $\mathrm{z}$ kwalifikacją na pracę licencjacka).

Małgorzata Winczura, Architektura i wyposażenie wnętrza kościola OO. Bernardynów pw. Podwyższenia Krzyża św. w Tarnowie, ss. 104, il. wbw. 28, Kraków 27.05.2002 (praca magisterska z kwalifikacją na pracę licencjacka).

Małgorzata Piwowarczyk, Geneza i ewolucja oltarza św. Stanistawa, biskupa i męczennika, w kościele parafialnym w Chrzanowie, ss. 118, il. 17 wbw., Kraków 10.06.2002.

Zuzanna Rasiewicz, Historia budowy $i$ wystroju kaplicy św. Rafała Kalinowskiego w Czernej, ss.97, i1. 17, Kraków 25.06.2002 (praca magisterska z kwalifikacją na pracę licencjacka).

Beata Szybuńka, Krakowskie motywy sakralne w twórczości Leona Wyczólkowskiego, ss. 163, il. 45, Kraków 25.06.2002 (praca magisterska z kwalifikacja na pracę licencjacka).

Ewa Horodyska-Talarek, Ikonografia św. Tekli. Wartości ideowo-artystyczne wizerunków świętej w sztuce chrześcijańskiej na podstawie wybranych przykladów. ss. 150, il. 70, Kraków 25.06.2002 (praca magisterska z kwalifikacja na pracę licencjacka).

Agnieszka Zabielska, Sladami kościola św. Szczepana $w$ Krakowie, ss. 125, il. 61, Kraków 25.06.2002 (praca magisterska z kwalifikacją na pracę licencjacka).

Agnieszka Suder, Barokizacja kościola pw. św. Katarzyny Aleksandryjskiej w Nowym Targu, ss. 83, il. 56, Kraków 21.10.2002 (praca magisterska z kwalifikacją na pracę licencjacka).

\section{Recenzje rozpraw habilitacyjnych}

Ocena dorobku naukowego i rozprawy habilitacyjnej ks. dr. Józefa Andrzeja Nowobilskiego nt. Mecenat artystyczny biskupa Jana Woronicza w Krakowie, Kraków 14.04.2002 r.

Ocena dorobku naukowego i rozprawy habilitacyjnej ks. dr. Andrzeja Witko nt. Sztuka w stużbie Zakonu Trójcy Swiętej w siedemnastym i osiemnastym stuleciu, bronionej w Instytucie Sztuki Polskiej Akademii Nauk w Warszawie, 21.11.2002 r., Kraków 20.09.2002 r.

Opinie na temat prac zgłaszanych do Dziekanatu Historii Kościoła

Opinia o pracy mgr Moniki Staszewicz nt. Sztuka Ludowa Prowansji, wydruk komputerowy, ss. 62, nlb. 4, Kraków 20.05.2002. 
Rok 2003

Recenzje prac licencjatu zawodowego

Ewa Paluch, Kościól Bożego Miłosierdzia przy ul. Smoleńsk w Krakowie, ss. 33, il. 54, 6 aneksów, Kraków 15.09.2003.

Elżbieta Augustyn, Symbolika scen pasyjnych na rewersach szafy brackiej $w$ kościele Bożego Ciala w Krakowie, ss. 31, il. kol. 1, Kraków 16.09.2003.

Agata Baster, Wartości artystyczne i zatożenia ideowe kaplicy Dzieciatka Jezus w kościele Karmelitów Bosych w Krakowie przy ul. Rakowickiej, ss. 38, il. 16, Kraków 16.09.2003.

Katarzyna Gniadek, Barok w kościele św. Katarzyny i św. Moniki w Krakowie z przylegajaca kaplicq Wegierskq, zwanq również św. Moniki, ss. 36, il. wbw. 29, Kraków 16.09.2003.

Agnieszka Niemiec, Garnizonowy kościót Św. Agnieszki w Krakowie, ss. 40, il. wbw. 9, Kraków 16.09.2003.

Katarzyna Ptak, Ikonografia Matki Bożej Piekarskiej, ss. 50, i1. 25, Kraków 16.09.2003.

Magdalena Petr, Kaplica Zmartwychwstania Pańskiego na cmentarzu Rakowickim w Krakowie, ss. 16, nlb 16, il. 14, Kraków 17.09.2003.

Magdalena Gałęzia, Przemiany kompozycyjne wizerunku św. Marii Magdaleny od średniowiecza do XX wieku w Krakowie, ss. 59, il. 17, Kraków 17.09.2003.

Artur Jałocha, Oltarz glówny w kościele ŚŚ. Piotra i Pawła w Krakowie, ss. 20, il. 6, Kraków 17.09.2003.

Mateusz Kołek, Ottarze $w$ kościele św. Anny w Krakowie, ss. 25, il. 7, Kraków 17.09.2003.

Mateusz Magiera, Epitafium Stanisława Mieroszewskiego $w$ kościele ŚS. Piotra i Pawla w Krakowie, ss. 17, il. 4, Kraków 17.09.2003.

Urszula Obodzińska, Wenus w oczach Botticellego, Tycjana i Rubensa, ss. 53 il.wbw. 12, Kraków 17.09.2003.

\section{Recenzje prac magisterskich}

Monika Biel, Życie i działalność ks. Sebastiana Alojzego Sierakowskiego w dziedzinie sztuki sakralnej, ss. 150, il. 33, Kraków 14.06.2003.

Jakub Lapczyński, Funkcja dydaktyczna muzeów diecezjalnych na przykładzie Muzeum Archidiecezjalnego w Krakowie, ss. 122, nlb 5, il. 18, Kraków 23.06.2003.

Anna Burtan, Zarys dziejów Podgórza i jego parafii pod wezwaniem św, Józefa, ss. 104, Kraków 06.12.2003.

Beata Warzecha, Wartości ideowe $i$ artystyczne kaplicy Matki Bożej Ostrobramskiej w kościele Karmelitów Bosych w Krakowie, ss. 114, il. 33, Kraków 13.12.2003 (praca magisterska z kwalifikacją na pracę licencjacka).

Marcin Borowski, Architektura oraz wystrój wnetrza kościola OO. Redemptorystów przy ul. Zamojskiego $56 \mathrm{w}$ Krakowie-Podgórzu, ss. 117, il. 56, Kraków 14.12.2003 (praca magisterska z kwalifikacja na pracę licencjacka). 
Recenzje prac licencjackich

Agnieszka Widacka, Malowidło ścienne ,nadanie reguty zakonnikom św. Augustyna” w krużgankach klasztoru OO. Augustianów w Krakowie. Studium stylu i ikonografii, ss. 55, il. 17, Kraków 18.05.2003 (ocena pracy magisterskiej jako licencjackiej).

Łucja Marek, Matka Boska Spytkowicka (dzieło Józefa Kopaczyńskiego) - krakowskie malarstwo religijne w sluzbie Kościolowi, ss. 107, il. 178, aneksów XIV, Kraków 19.05.2003 (ocena pracy magisterskiej jako licencjackiej).

Magdalena Jędrzejczyk, Architektura i wyposażenie kościola pod wezwaniem św. Jana Chrzciciela $i$ św. Jana Ewangelisty w Krakowie w kontekście jego dziejów, ss. 108, i1. 21, Kraków 17.12.2003.

Rok 2004

Recenzje prac magisterskich

Symforian Roman Rygiel OFM, Architektura i zabytowe wyposażenie cerkwii pod wezwaniem Chrystusa Króla w Trzcianie koło Dukli, ss. 101, il. 110, Kraków 12.01.2004.

\section{Recenzje wydawnicze}

Ocena wydawnicza naukowej pracy prof. Tomasza M. Trajdosa pt. U zarania karmelitów w Polsce, Warszawa 1991, mps ss. 301, Warszawa?

Opinia wydawnicza pracy prof. dr. hab. Jana Samka pt. Dzieje sztuki Krakowa przeznaczonej dla pedagogów, przewodników i miłośników Krakowa. Kraków 26.06.1997.

Recenzja wydawnicza ksiażki prof. dr. hab. Jana Samka pt. Dzieje sztuki Polskiej dla pedagogów, Przemyśl 1998, Kraków 15.11.1998 r. [w:] Dzieje sztuki Polskiej dla pedagogów, Kraków-Przemyśl 1999, s. 7-9.

Recenzja wydawnicza książki ks. đr. Zdzisława Klisia pt. Paruzja. Przedstawienie Sqdu Ostatecznego w sztuce średniowiecznej Europy Środkowej, Kraków 1999. Kraków 01.06.1999 r.

Recenzja wydawnicza ksiązki dr Anety Karmiszewskiej nt. Visio religiosa w polskiej sztuce barokowej. Ze studiów nad ikonografiq hagiograficznq, Lublin 2000. Kraków 02.06.2002 r.

Recenzja wydawnicza pracy Piotra Franciszka Neumann OCD nt. Wykaz personalny klasztorów diecezji poznańskiej z 1812 roku. Rękopis OA II 40 w Archiwum Archidiecezjalnym w Poznaniu, ss. 31, w tym 3 tabele. Kraków 26.11.2002.

Opinia wydawnicza o pracy mgr Agnieszki Perzanowskie nt. Rewizje domów Krakowskiëj Kapituły Katedralnej. Inwentarz archiwalny. Kraków 03.0.07.2003 r.

Recenzja wydawnicza artykułu ks. Henryka Nadrowskiego nt. Obraz, symbol, słowo. Inspiracje i kreacje, ss. 23. Kraków 05.08.2003.

Recenzja wydawnicza artykuhu Krzysztofa Kaczmarka OP, Konwent dominikanów poznańskich w średniowieczu, opublikowanego w: Ecclesia Studia z dziejów Wielkopolski, t. I, 2003, Uniwersytet im. Adama Mickiewicza, Wydział Teologiczny, Poznań 2003, s. 35-54. 
Recenzja wydawnicza artykułu Piotra Franciszka Neumann OCD, Dobrodzieje poznańskich karmelitów bosych w XVII i pierwszej polowie XVIII wieku, opublikowanego w: Ecclesia Studia z dziejów Wielkopolski, t. I, 2003, Uniwersytet im. Adama Mickiewicza, Wydział Teologiczny, Poznań 2003, s. 55$-96$.

Recenzja wydawnicza artykuh Piotra Franciszka Neumann OCD, Kardynal Ledóchowski w świetle kronik karmelitanek, opublikowanego w: Ecclesia Studia z dziejów Wielkopolski, t. I, 2003, Uniwersytet im. Adama Mickiewicza, Wydział teologiczny, Poznań 2003, s.179-196.

Opinie o naukowej działalności

Opinia o naukowej i dydaktycznej działalności prof. dr. hab. Jana Samka, Kraków 18.09.1999.

Ocena dorobku naukowego ks. dr. hab. Zdzisława Klisia po habilitacji, Kraków 03.01.2004.

\section{Opracowania (redakcja)}

Kronika, Redagowanie karmelitańskiej kroniki w czasopiśmie „Juventus Teresiana" od września 1957 r. nr 5(7) do grudnia 1958 r. nr 4(12).

Wprowadzenie i redakcja, [w:] O. Kajetan Furmanik OCD, Księga zmarlych ojców i braci karmelitów bosych prowincji polskiej Ducha Świętego od roku 1881 do 1998, Kraków 1998, Kuria Krakowskiej Prowincji Karmelitów Bosych, s. $5-9$.

Wprowadzenie i redakcja, [w:] o. Kajetan Furmanik OCD, Księga zmartych karmelitów bosych w Polsce, na Litwie i Rusi 1607-1998, t. I/1-2, Prowincja Polska pw. Ducha Świętego 1607-1750, Kuria Krakowskiej Prowincji Karmelitów Bosych, Kraków 2002, s. 5-6.

Wstęp - wprowadzenie, [w:] Maria Ksawera od Jezusa z Grocholskich Czartoryska OCD, Największe Miłosierdzie Boze! Reforma Czernej, Kraków 2000, Kuria Krakowskiej Prowincji Karmelitów Bosych s. 6-26.

Opracowanie i posłowie, [w:] Maria Ksawera Czartoryska OCD, Reforma CzemejNajwiększe Mitosierdzie Boże, „Nasza Przeszłość”, t. 95: 2001, s. 261-356.

Opracowanie i posłowie, [w:] O. Daniel Maria od Najśw. Serca Pana Jezusa, karmelita bosy (Oswald Rufeisen), Polknątem haczyk Królowej Karmelu, Autobiografia, Wydawnictwo Karmelitów Bosych, Kraków 2001, s. 293, 32 nlb., il. wbw. 31.

Wstęp - wprowadzenie, [w:] O. Daniel Maria od Najśw. Serca Pana Jezusa, Dzienniczek duchowy z lat 1945-1947, Kraków 2002, Kuria Krakowskiej Prowincji Karmelitów Bosych s. 3-5.

Inne

Easkami stynacy obraz św. Józefa patrona miasta Krakowa, Rzym 1981, ss. 6, folder $z 1$ ilustracja. 
Matka Boża Szkaplerzna w Czernej, folder, Wydawnictwo XX Pallottynów w Ząbkach 1987, s. 4, nlb 4, il. 3 barwne, nakład 20000 egz.

Historia sztuki kościelnej w zarysie, Skrypt dla studentów PAT, zebrał i opracował o. B. J. Wanat OCD, Kraków 1999, ss. 196.

Opublikowane kazania i homilie

Homilia wygłoszona podczas Mszy św. w Sosnowcu 31 XII 2001, z okazji 80 rocznicy założenia Zgromadzenia Sióstr Karmelitanek Dzieciątka Jezus, „Pod znakiem Dzieciątka Jezus", nr 2(2002), s. 14-20.

Uroczystość Zwiastowania Pańskiego - kazanie o. prof. dra hab. Benignusa Józefa Wanata OCD, wygtoszone dnia 8 kwietnia 2002 w kaplicy Domu Generalnego Zgromadzenia Sióstr Najświętszej Duszy Chrystusa Pana w Krakowie, z okazji święta patronalnego Zgromadzenia, „Promyk Duszy Chrystusowej” - kwartalnik wydawany przez Dom generalny Zgromadzenia Sióstr Najświętszej Duszy Chrystusa Pana w Krakowie - nr 2(10)2002, s. 4-10.

Uroczystość Trójcy Przenajświętszej - kazanie o. prof. dra hab. Benignusa Józefa Wanata OCD, wygtoszone dnia 26 maja 2002 w kaplicy Domu Generalnego Zgromadzenia Sióstr Najświętszej Duszy Chrystusa Pana w Krakowie, z okazji święta patronalnego Zgromadzenia, „Promyk Duszy Chrystusowej", nr 2 (10) rok 2002, s. 11-17. 